\section{Genetic Variability for Yield and Nutritional Quality in Yam Bean (Pachyrhizus sp.)}

\author{
Rolland Agaba ${ }^{2}$, Phinehas Tukamuhabwa, and Patrick Rubaihayo \\ Department of Agricultural Production, College of Agricultural and \\ Environmental Sciences, Makerere University, P.O. Box 7062, Kampala, \\ Uganda
}

Silver Tumwegamire ${ }^{1}$, Andrew Ssenyonjo, and Robert O.M. Mwanga
International Potato Center, P.O. Box 22274, Kampala, Uganda

Jean Ndirigwe

Rwanda Agriculture Board, P.O. Box 5016, Kigali, Rwanda

\author{
Wolfgang J. Grüneberg \\ International Potato Center, Apartado 1558, Lima 12, Peru
}

Additional index words. American yam bean, genetic variation, variance components, heritability, yield components, nutritional quality, Uganda

\begin{abstract}
The amount of genotypic and phenotypic variability that exists in a species is important for selection and initiating breeding programs. Yam bean is grown locally in tropical countries of the Americas and Asia for their tasty storage roots, which usually have low dry matter content. The crop was recently introduced in Uganda and other East and Central African countries to supplement iron ( $\mathrm{Fe}$ ) and protein content in diets. This study aimed to estimate genetic variability for root yield and quality traits among 26 yam bean accessions in Uganda. A randomized complete block design was used with two replications across two ecogeographical locations and two seasons during 2012 and 2013. Near-infrared reflectance spectroscopy (NIRS) was used to determine quality of storage root samples. Significant differences among genotypes were observed for all traits except root protein, zinc ( $\mathrm{Zn})$, and phosphorus contents. Genotypic variance components $\left(\sigma_{G}^{2}\right)$ were significant for storage root fresh yield (SRFY), storage root dry matter (SRDM), storage root dry yield (SRDY), vine yield (VNY), fresh biomass yield (FBY), and storage root starch (STA) and Fe contents. For traits with significant $\sigma_{G}^{2}$, the broad sense heritability estimates ranged from $58.4 \%$ for SRDY to $83.6 \%$ for FBY; and phenotypic coefficients of variation were high for SRFY (66\%), SRDY $(53.3 \%)$, VNY $(60.5 \%)$, and FBY $(59 \%)$, but low to medium for SRDM $(22.6 \%)$, STA $(15.1 \%)$, and Fe $(21.3 \%)$. Similarly, the genotypic coefficients of variation were high for SRFY (56.7\%), SRDY $(53.3 \%)$, VNY (55\%), and FBY (53.9\%); and low for SRDM (20\%), STA $(12.4 \%)$, and Fe $(\mathbf{1 7 . 8 \%})$. There were strong positive correlations between SRFY and both SRDY $(r=$ $0.926)$ and FBY $(r=0.962)$, but low-to-moderate correlations among quality traits. It should be possible to breed for high dry matter yam beans by using low dry matter accessions due to the observed genetic variation $\left(\sigma_{G}^{2}=9.3 \%\right.$, which is important if the high dry matter Pachyrhizus tuberosus accessions (known as chuin) from Peru cannot be accessed. This study indicated substantial genetic variation for yield and quality traits in yam bean, demonstrating potential for adaptability to growing conditions and consumer needs in East and Central Africa and for genetic improvement through selection.
\end{abstract}

Yam bean is a legume that forms storage roots (Sørensen, 1996). Roots and tubers produced by legumes have long been recognized as a good food source, and they have been recommended for human nutrition (FAO, 1979). Nonetheless, the use of legume root crops is very limited, except for yam beans with low contents of SRDM, of around $20 \%$, which are appreciated for their refreshing taste. Yam beans originated in tropical America and the crop group comprises three closely related cultivated species: Pachyrhizus erosus (Mexican yam bean), Pachyrhizus ahipa (Andean yam bean), and P. tuberosus (Amazonian yam bean). Interspecific crosses among $P$. ahipa and $P$. tuberosus (Grüneberg and sankeh alu in India; and dòushǔ and liáng shǔ in China. In Africa, the crop so far has no local names. The recently identified $P$. tuberosus type, with the local name chuin, in Peru showed that yam beans can also have very high SRDM of $\approx 30 \%$.

Yam bean has several attractive attributes for farming systems in the developing world. The main attributes are storage root yields, nitrogen fixation, short crop duration, and higher nutritional values than traditional tropical root and tuber crops such as cassava (Manihot esculenta Crantz) and sweetpotato [Ipomoea batatas (L.) Lam.]. The crop can have very high yields of edible storage roots, up to $\approx 80 \mathrm{t} \cdot \mathrm{ha}^{-1}$ fresh weights in on-station trials (Sørensen, 1996; Zanklan et al., 2007). As a legume, yam bean can improve soil fertility through nitrogen fixation (Castellanos et al., 1997; Rodríguez-Navarro et al., 2009). The crop was introduced to Uganda in 2010 to evaluate the adaptation, nutrition, and processing options under East and Central African growing conditions. In Africa to date, the three cultivated yam bean species have mainly been evaluated in Benin by Zanklan et al. (2007), with current on-farm yield estimates for two P. erosus accessions (CIP-209018 and CIP-209019) averaging $\approx 24 \mathrm{t} \cdot \mathrm{ha}^{-1}$ (Grüneberg, 2016). Storage root mean yields of $14-17 \mathrm{t} \cdot \mathrm{ha}^{-1}$ were reported for $P$. erosus accessions in other West African countries (Annerose and Diouf, 1998; Belford et al., 2001). The crop has short growth cycles (4-6 months), which should allow two harvests per year at many locations in Africa. With respect to breeding, all cultivated yam beans are mainly self-pollinating, but up to $30 \%$ outcrossing occurs depending on the presence of pollinators (mainly bees) so that line breeding is practiced (Sørensen, 1996). Its attributes make the crop attractive for evaluation in Central and East Africa.

The crop has additional attractive traits such as propagation by true seed, minimal pest incidence due to insecticidal polyphenols in shoots and pods, wide geographic adaptation even in semiarid conditions, and high Fe content (Zanklan et al., 2007). Yam bean storage roots contain $56 \%$ to $58 \%$ of starch (Forsyth et al., 2002) and $8 \%$ to $18 \%$ protein (Velasco and Grüneberg, 1999) both on a dry weight basis, and vitamins viz. ascorbic acid, thiamine, riboflavin, pyridoxine, niacin and folic acid, and micronutrients, such as Fe, magnesium, and $\mathrm{Zn}$ (Dini et al., 2013; Noman et al., 2007; Ramos-de-la-Peña et al., 2013). Yam bean storage roots are usually consumed raw, mainly as a root fruit/ vegetable (Gupta et al., 2003; Park and Han, 2015) because of the high moisture content of more than $80 \%$ fresh weight (Grüneberg et al., 2003); however, the recently found chuin type of $P$. tuberosus has storage root moisture content of $\approx 70 \%$. For the chuin, dry matter content in storage roots of $26 \%$ to $36 \%$ has been reported (Grüneberg et al., 2003; Zanklan et al., 2007), but these accessions are protected under national rights of Peru and were not available for study in East and Central Africa. Interestingly, yam bean 
storage roots can be processed into gari, a staple in West Africa, usually made from cassava (Padonou et al., 2013; Zanklan et al., 2007). However, the seed of the crop cannot be used as food due to presence of rotenone and its derivatives (Grüneberg et al., 1999; Lautié et al., 2013), but the attribute of true seed propagation without the need for stem or vine cuttings for planting might make dissemination efforts and maintaining seeds less expensive compared with other root and tuber crops in Africa.

The yam bean germplasm introduced into Uganda remains largely uncharacterized, except for composition, and physicochemical characteristics of seed flour (Kisambira et al., 2014, 2015). Unfortunately, the yam bean germplasm in Uganda does not include the chuin type of $P$. tuberosus with high SRDM. The SRDM trait is of special interest as root and tuber crops in Africa such as cassava and sweetpotato have much higher SRDM than the traditional yam bean, excluding the chuins. Mean, minimum, and maximum genotypic values and magnitudes of variance components for yield and nutritional quality traits provide information for better understanding of germplasm properties. Similarly, genotypic and phenotypic variation coefficients (GCV and PCV, respectively) give a measure of the variability in a given population (Abinasa et al., 2011). The objective of this study was to estimate genotypic means, variance components, broad sense heritability, GCV, PCV, and correlations for yield components [i.e., SRFY, SRDY, VNY, FBY, and harvest index (HI)] and nutritional quality traits [i.e., SRDM, starch (STA), protein (PRO), Fe, $\mathrm{Zn}$, potassium $(\mathrm{K})$, and phosphorus $(\mathrm{P})]$ among 26 yam bean accessions available in Uganda.

\section{Materials and Methods}

Experimental sites and germplasm. Field experiments were carried out in two distinct agroecological locations in Uganda: the National Crops Resources Research Institute (NaCRRI) at Namulonge and the National Semi Arid Resources Research Institute at Serere (Supplemental Table 1). Namulonge

Received for publication 9 Feb. 2016. Accepted for publication 21 June 2016.

We acknowledge the International Potato Center (CIP) and the Belgium Development Corporation (BTC) for funding this research. We are also grateful for field and laboratory facilities from the National Crops Resources Research Institute (NaCRRI) and National Semi Arid Resources Research Institute (NaSARRI), Uganda. We thankfully recognize Peter Sallah at College of Agriculture and Veterinary Medicine (CAVM), University of Rwanda for support in data analysis and comments on earlier drafts of the manuscript. This paper is a portion of a $\mathrm{PhD}$ research thesis at Makerere University, Uganda, by Rolland Agaba. ${ }^{1}$ Current address: International Institute of Tropical Agriculture, P.O. Box 34441, Dar es Salaam, Tanzania ${ }^{2}$ Corresponding author. E-mail: rondessblessed@ gmail.com. is located in the central region and is characterized by bimodal rainfall, red ferralitic soils, and low soil $\mathrm{pH}$. Serere is located in the eastern agroecological zone and is characterized by longer periods of drought, erratic rainfall patterns, and sandy loam soils with moderate soil $\mathrm{pH}$.

A total of 26 yam bean accessions representing the three cultivated species (10 of $P$. ahipa, 11 of $P$. erosus, and 5 of $P$. tuberosus) from the gene bank of the International Potato Center (CIP) in Lima, Peru, were used in this study (Table 1). We sought to determine whether the variability in the yam bean genepool would be sufficient to initiate a breeding program for the crop in East and Central Africa. Under the framework of the AHIPA project, the accessions were introduced in 2010 in four East and Central African countries: Uganda, Rwanda, Burundi, and D.R. Congo (Grüneberg, 2007a, 2007b; Heider et al., 2011).

Experimental design and agronomic practices. A randomized complete block design was established for two growing seasons in Apr. 2012 and 2013, respectively with two plot replications at each experimental site. Each plot comprised two 3-m-long ridges that were $1 \mathrm{~m}$ apart. On each ridge, 10 seeds of each yam bean accession were planted at a $30 \mathrm{~cm}$ spacing to achieve a target population of 33,333 plants/ha.

The major agronomic practice was reproductive pruning, which is a common production procedure for yam bean farmers in the Americas and Asia (Sørensen, 1996). This practice usually involves pruning flower buds and leaving only one pod on each plant or a selected few plants dedicated to seed production (Delêtre et al., 2013; Zanklan et al., 2007). In this study, all flower buds were continuously removed weekly beginning at the first flower bud formation to reduce flower-root sink competition for nutrients and photosynthate. The practice encourages storage root formation (Forsyth and Shewry, 2002) and enhances storage root yields (Leidi et al., 2004; Matos et al., 1998; Rizky et al., 2013) by $70 \%$ to $100 \%$ in yam beans (Zanklan et al., 2007). The experiments were kept weed-free and neither fertilizers nor agrochemicals were applied during the growing periods.

Data collection. Yam bean plants were harvested individually at maturity, 6 months after planting, and data were recorded on the numbers of harvested plants with and without storage roots. Storage roots were detached using a field knife collected into a pile per plot and data recorded for the numbers of large $(>100 \mathrm{~g})$ and small roots $(<100 \mathrm{~g})$, and weight of fresh storage roots and aboveground foliage. SRFY, VNY, and FBY $(\mathrm{FBY}=\mathrm{SRFY}+\mathrm{VNY})$ were recorded as $\mathrm{kg} \cdot \mathrm{m}^{-2}$, whereas HI $(\mathrm{HI}=100 \times \mathrm{SRFY} / \mathrm{FBY})$ was computed as percentage (Table 2). From each pile, three to five fresh storage roots were randomly collected for nutritional quality analysis.

Storage root samples were processed in the quality laboratory at NaCRRI. The samples were washed with flowing tap water and rinsed with deionized water, peeled, and cut longitudinally into four sections using a stainless steel knife. Two opposite sections of each storage root slice were taken to prepare a compound sample of $100 \mathrm{~g}$ fresh weight. Each sample was packaged in transparent polythene bags and vacuum-freeze dried at $-31{ }^{\circ} \mathrm{C}$ for $72 \mathrm{~h}$ (using a vacuum-freeze drier, YK-118-50; True-Ten Industries, Korea) to obtain dry weight and freeze-dried samples for further quality determination. SRDM content was calculated as the average difference between fresh and dry weight estimates (fresh weight - dry weight $=$ dry matter) according to Wilken et al. (2008) and recorded as percentage. SRDM was used to estimate SRDY $(\mathrm{SRDY}=\mathrm{SRDM} \times \mathrm{SRFY} /$ $100)$, recorded as $\mathrm{kg} \cdot \mathrm{m}^{-2}$. Each freeze-dried sample was milled into flour using a stainless steel mill (Dayton split phase motor-3383L70, Thomas Scientific) fitted with a 0.425 $\mathrm{mm}$ sieve. The flour samples were stored in Kraft paper bags in deep freezers at $-20{ }^{\circ} \mathrm{C}$ until analysis.

Freeze-dried samples were analyzed by NIRS to determine root PRO, STA, Fe, Zn, K, and $\mathrm{P}$ as described by Velasco and Grüneberg (1999) in yam bean with modifications, using milled flour obtained from freeze-dried storage root samples as described by Tumwegamire et al. (2011) for sweetpotato. PRO and STA were recorded as percentage, $\mathrm{Fe}$ and $\mathrm{Zn}$ as $\mathrm{mg} \cdot \mathrm{kg}^{-1}$, and $\mathrm{K}$ and $\mathrm{P}$ as $\mathrm{mg} / 100 \mathrm{~g}$ (all on a dry weight basis). The NIRS calibrations for yam bean freeze-dried storage root samples are available at the quality laboratory at NaCRRI in Uganda and the plant and nutrition quality laboratory at CIP in Peru. Each flour sample

Table 1. Characteristics of 26 yam bean accessions evaluated for yield components and nutritional quality in Uganda during 2012 and 2013 early growing seasons.

\begin{tabular}{llll}
\hline CIP $^{z}$ code & \multicolumn{1}{c}{ Species } & Plant type & \multicolumn{1}{c}{ Origin } \\
\hline 209004 & P. ahipa & Bushy-erect & Bolivia \\
209006 & P. ahipa & Bushy-erect & Bolivia \\
209007 & P. ahipa & Bushy-erect & Bolivia \\
209016 & P. erosus & Climbing & Guatemala \\
209017 & P. erosus & Climbing & Brazil \\
209018 & P. erosus & Climbing & China \\
209019 & P. erosus & Climbing & Mexico \\
209023 & P. ahipa & Bushy-erect & Bolivia \\
209025 & P. ahipa & Bushy-erect & Bolivia \\
209027 & P. ahipa & Bushy-erect & Bolivia \\
209028 & P. ahipa & Bushy-erect & Bolivia \\
209031 & P. ahipa & Bushy-erect & Bolivia \\
209033 & P. ahipa & Bushy-erect & Bolivia \\
209034 & P. ahipa & Bushy-erect & Argentina \\
209046 & P. erosus & Climbing & Costa Rica \\
209047 & P. erosus & Climbing & Mexico \\
209048 & P. erosus & Climbing & Costa Rica \\
209049 & P. erosus & Climbing & Mexico \\
209050 & P. erosus & Climbing & Mexico \\
209051 & P. erosus & Climbing & Mexico \\
209052 & P. erosus & Climbing & Tonga \\
209055 & P. tuberosus & Climbing & Brazil \\
209057 & P. tuberosus & Climbing & Brazil \\
209058 & P. tuberosus & Climbing & Brazil \\
209060 & P. tuberosus & Climbing & Tonga \\
209061 & P. tuberosus & Climbing & Tonga \\
\hline
\end{tabular}

${ }^{\mathrm{z}}$ International Potato Center. 
was scanned three times by NIRS to obtain replicates of near-IR spectra output of each sample within the range of 400-2500 nm using NIRS system 5000-M, FOSS Scientific 2000 (Ozaki et al., 2006).

Data analysis. Statistical analysis was carried out in four steps: 1) determination of outliers, and means for locations and seasons; 2) analysis of variance (ANOVA) with two models, with the first considering seasons as random, and the second estimating variance components and therefore considering all factors as random (factor "season" was considered as random in the first model because factor levels are not reproducible, whereas all factors were considered random in the second model for estimating variance components because chosen genotypes, locations, and seasons are items of a given population); 3) estimating PCV (\%) and GCV (\%) and broad sense operative heritability $\left(\mathrm{H}^{2}\right)$; and 4) determination of correlation coefficients among traits. For each analysis step the data were, respectively, classified into genotypes $(\mathrm{G})$, locations $(\mathrm{L})$, growing seasons (S), blocks (B), and replications. Note, when results of the first ANOVA model were available, the factors "season" and "location" were aggregated into the factor "environment"; the second ANOVA model remained unchanged. Data were analyzed using PLABSTAT (Utz, 1997) and the GenStat $14^{\text {th }}$ edition computer software package (Payne et al., 2011).

In the first analysis step, each trait $x_{i}$ (i.e., SRFY, SRDY, VNY, FBY, HI, SRDM, PRO, STA, Fe, Zn, K, and P) was analyzed to determine outliers, means for locations and season, and least significant differences (LSDS) as descriptive value (Table 4). This was conducted using PLABSTAT with the model statement $x_{i}=\mathrm{S}+\mathrm{L}+\mathrm{SL}+\mathrm{G}+\mathrm{GS}+$ $\mathrm{GL}+\mathrm{GSL}+\mathrm{B}: \mathrm{SL}+\mathrm{BGSL}$, which corresponds to the following statistical model:

$$
\begin{aligned}
Y_{i j k l n}= & \mu_{i}+s_{i j}+l_{i k}+s l_{i j k}+g_{i l}+g s_{i l j} \\
& +g l_{i l k}+g s l_{i l j k}+b(s l)_{i n(j k)}+\varepsilon_{i l j k n}
\end{aligned}
$$

where $Y_{i j k l n}$ is the plot value of the $i$ th trait of the $j$ th season, for location $k$, for the $l$ th genotype and $n$th block; $\mu_{i}$ is the trial mean of the $i$ th trait; $s_{i j}, l_{i k}, g_{i l}, s l_{i j k}, g s_{i l j}, g l_{i l k}$, and $g s_{l i l j k}$ are the effects of $\mathrm{S}, \mathrm{L}, \mathrm{G}$, and $\mathrm{S} \times \mathrm{L}$, $\mathrm{G} \times \mathrm{S}, \mathrm{G} \times \mathrm{L}$, and $\mathrm{G} \times \mathrm{S} \times \mathrm{L}$ interactions, respectively; $b(s l)_{i n(j k)}$ is the effect of blocks; and $\varepsilon_{i l j k n}$ is the plot error. In this analysis step, all effects where $\mathrm{S}$ was involved were treated as random while $\mathrm{L}$ and $\mathrm{G}$ were treated as fixed.

In the second analysis step, significance tests and variance component estimations were conducted. Each trait $x_{i}$ was analyzed

Table 2. Agronomic and nutritional quality traits evaluated in 26 accessions at two locations and two

\begin{tabular}{|c|c|c|}
\hline Traits & Code & Procedure and time of recording \\
\hline Storage root fresh yield & SRFY & $\begin{array}{l}\mathrm{kg} \cdot \mathrm{m}^{-2} \text {, at physiological maturity, } 20 \text { plants } \\
\text { from two rows, fresh weight }\end{array}$ \\
\hline Vine and leaf weight & VNY & $\begin{array}{l}\mathrm{kg} \cdot \mathrm{m}^{-2} \text {, at physiological maturity, } 20 \text { plants } \\
\text { from two rows, fresh weight }\end{array}$ \\
\hline Fresh biomass yield & FBY & $\mathrm{kg} \cdot \mathrm{m}^{-2}, \mathrm{SRFY}=\mathrm{SRFY}+\mathrm{VNY}$ \\
\hline Harvest index for storage root & $\mathrm{HI}$ & $\%, \mathrm{HI}=(\mathrm{SRFY} / \mathrm{FBY}) \times 100$ \\
\hline Storage root dry matter content & SRDM & $\%$, according to Wilken et al. (2008) \\
\hline Storage root dry matter yield & SRDY & $\mathrm{kg} \cdot \mathrm{m}^{-2}, \mathrm{SRDY}=\mathrm{SRDM} \times \mathrm{SRFY} / 100$ \\
\hline Protein root content & PRO & $\%$ in SRDM, by NIRS \\
\hline Starch root content & STA & $\%$ in SRDM, by NIRS \\
\hline Iron root content & $\mathrm{Fe}$ & $\mathrm{mg} \cdot \mathrm{kg}^{-1}$ in SRDM, by NIRS \\
\hline Zinc root content & $\mathrm{Zn}$ & $\mathrm{mg} \cdot \mathrm{kg}^{-1}$ in SRDM, by NIRS \\
\hline Potassium root content & $\mathrm{K}$ & $\mathrm{mg} / 100 \mathrm{~g}$ in SRDM, by NIRS \\
\hline Phosphorus root content & $\mathrm{P}$ & $\mathrm{mg} / 100 \mathrm{~g}$ in SRDM, by NIRS \\
\hline
\end{tabular}
seasons, codes, measurement units, and measurement procedures.

SRDY = storage root dry yield; $\mathrm{VNY}=$ vine yields; FBY = fresh biomass yield; $\mathrm{HI}=$ harvest index; $\mathrm{PRO}=$ protein; STA = starch; Fe = iron; $\mathrm{K}=$ potassium; $\mathrm{Zn}=$ zinc; $\mathrm{P}=$ phosphorus; NIRS = near-infrared reflectance spectroscopy; SRFY = storage root fresh yield. using the above given statistical model, considering the two forms of treating the effects as fixed or random. In the first form, the effects $l_{i k}, g_{i l}$, and $g l_{i l k}$ were treated as fixed, and all remaining effects as random to determine mean square values and $\mathrm{F}$ tests for each effect (Table 3 ). This was linked with calculation of means of genotypes across seasons and locations, and LSD values for the main effect $g_{i l}$. In the second form of treating effects in the above given statistical model, all effects were considered to be random, and variance components due to $G$ $\left(\sigma_{G}^{2}\right), \mathrm{G} \times \mathrm{S}\left(\sigma_{G x S}^{2}\right), \mathrm{G} \times \mathrm{L}\left(\sigma_{G x L}^{2}\right), \mathrm{G} \times \mathrm{S} \times \mathrm{L}$ $\left(\sigma_{G x S x L}^{2}\right)$, and the error term $\left(\sigma_{\varepsilon}^{2}\right)$ were calculated (Table 5).

In a third analysis step, GCV and PCV were calculated as suggested by Burton and Devane (1953) and Singh and Chaudhary (1985), and $H_{b}^{2}$ according to Falconer and Mackay (1996):

$$
\begin{aligned}
& G C V(\%)=\frac{\sqrt{\sigma_{G}^{2}}}{\bar{x}_{i \ldots}} * 100, \\
& \operatorname{PCV}(\%)=\frac{\sqrt{\sigma_{P}^{2}}}{\bar{x}_{i \ldots}} * 100,
\end{aligned}
$$

$$
\begin{aligned}
H_{b}^{2} & =\frac{\sigma_{G}^{2}}{\sigma_{\bar{P}}^{2}} * 100 \\
& =\frac{\sigma_{G}^{2}}{\left(\sigma_{G}^{2}+\frac{\sigma_{G X S}^{2}}{s}+\frac{\sigma_{G x L}^{2}}{l}+\frac{\sigma_{G \times S x L}^{2}}{s * l}+\frac{\sigma_{\varepsilon}^{2}}{s * l * r}\right)} * 100,
\end{aligned}
$$

where $\bar{x}_{i} \ldots$ is the overall trait mean; $\mathrm{s}, 1$, and $\mathrm{r}$ are the number of seasons, locations, and replications, respectively.

In the final analysis step, Pearson's phenotypic correlation coefficients among traits were calculated. The correlations were calculated for each season, location, and replication separately, followed by calculating the average correlation between each trait pair across seasons, locations, and replications

\begin{tabular}{|c|c|c|c|c|c|c|c|}
\hline \multirow[b]{2}{*}{ Source of variation } & \multirow[b]{2}{*}{$\mathrm{df}$} & \multicolumn{6}{|c|}{ Mean squares for yield components } \\
\hline & & $\begin{array}{l}\text { Storage root } \\
\text { fresh yield }\end{array}$ & $\begin{array}{c}\text { Storage root } \\
\text { dry yield }\end{array}$ & Vine yield & $\begin{array}{c}\text { Fresh } \\
\text { biomass yield }\end{array}$ & Harvest index & $\begin{array}{l}\text { Storage root } \\
\text { dry matter }\end{array}$ \\
\hline Environment (E) & 3 & $2,369.3^{*}$ & $35.9 *$ & $146.7 *$ & $3,569.1^{*}$ & $1,272.0$ & $284.0 * *$ \\
\hline Block (B) & 4 & $219.5^{*}$ & $3.2 *$ & $16.3 *$ & $273.9 *$ & $815.5 *$ & 10.4 \\
\hline Genotype (G) & 25 & $571.2 * *$ & $8.3 * *$ & 68.5 & $908.7 * *$ & $1,003.0 *$ & $95.0 * *$ \\
\hline $\mathrm{G} \times \mathrm{E}$ & 75 & $129.9 * *$ & $2.8 * *$ & $43.6 * *$ & $424.4 * *$ & $798.0 * *$ & $10.0 * *$ \\
\hline \multirow[t]{2}{*}{ Error } & & 64.8 & 1.3 & 5.0 & 82.9 & 265.4 & 4.4 \\
\hline & & \multicolumn{6}{|c|}{ Mean squares for root quality traits ${ }^{z}$} \\
\hline Source of variation & df & Protein & Starch & Iron & Zinc & Potassium & Phosphorus \\
\hline Environment (E) & 1 & $102.1 * *$ & 30.4 & $1,622.1^{* *}$ & $244.6^{* *}$ & 921,037 & $93,208 * *$ \\
\hline Block (B) & 4 & 3.0 & $281.1^{*}$ & 12.3 & 12.2 & 72,961 & 3,683 \\
\hline Genotype (G) & 25 & 3.9 & $480.1 * *$ & $195.2 * *$ & $15.5^{*}$ & $499,273 *$ & 5,102 \\
\hline $\mathrm{G} \times \mathrm{E}$ & 75 & 3.0 & $162.4^{*}$ & 80.2 & $8.4^{*}$ & $287,045^{* *}$ & $4,745^{*}$ \\
\hline Error & & 2.4 & 111.4 & 123.9 & 5.2 & 127,283 & 3,052 \\
\hline
\end{tabular}
(Table 6). These phenotypic correlations are considered a good approximation of genotypic correlation estimates (Hill et al., 1998).

Table 3. Mean squares for yield components and nutritional quality traits from analysis of variance.

$*, * *$ Significant at $P<0.05$ and 0.01 , respectively.

${ }^{\mathrm{z}}$ On a dry weight basis. 


\section{Results}

For most traits, environmental means at Namulonge and Serere clearly differed, except for SRDY, VNY, HI, and STA content (Supplemental Table 2). Means of all traits were higher at Namulonge than Serere, except for SRDM and VNY. There were striking differences between seasons, 2012 and 2013 at Namulonge, for SRFY, FBY, SRDY, VNY, and $\mathrm{PRO}, \mathrm{Fe}, \mathrm{Zn}$, and $\mathrm{P}$ content (Supplemental Table 2). Similarly, seasonal differences were striking in all traits at Serere, except for HI, SRDM, and STA content. Environment main effects were significant for all traits except HI, STA, and K (Table 3). Namulonge in 2012 was the best performing environment with respect to yield traits, with highest values for SRFY $\left(22.1 \mathrm{~kg} \cdot \mathrm{m}^{-2}\right)$, SRDY $\left(2.7 \mathrm{~kg} \cdot \mathrm{m}^{-2}\right)$, FBY $\left(26.4 \mathrm{~kg} \cdot \mathrm{m}^{-2}\right)$, and $\mathrm{HI}(84.6 \%)$; while Namulonge in 2013 was the best for quality traits: PRO (11.2\%), STA $(52.3 \%)$, Fe (28.7 $\left.\mathrm{mg} \cdot \mathrm{kg}^{-1}\right), \mathrm{Zn}\left(15 \mathrm{mg} \cdot \mathrm{kg}^{-1}\right)$, and P $(268 \mathrm{mg} / 100$ g) content (Supplemental Table 2). Serere in 2013 was the poorest performing environment for SRFY $\left(6.2 \mathrm{~kg} \cdot \mathrm{m}^{-2}\right)$, SRDY $\left(0.9 \mathrm{~kg} \cdot \mathrm{m}^{-2}\right)$, FBY $\left(9 \mathrm{~kg} \cdot \mathrm{m}^{-2}\right)$, HI $(72.4 \%)$, STA $(50.4 \%)$, and $\mathrm{K}(815 \mathrm{mg} / 100 \mathrm{~g})$ (Supplemental Table 2).

The ANOVA after aggregating $\mathrm{L}$ and $\mathrm{S}$ into the new factor environment $(\mathrm{E})$ [because $\mathrm{L}$ and $\mathrm{L} \times \mathrm{S}$ interactions were not significant (Supplemental Table 3)] revealed significant main effects of genotypes for all yield traits, except VNY (Table 3), and several quality traits (i.e., SRDM, STA, Fe, Zn, and P). The E main effects were also significant for all yield traits (i.e., SRFY, SRDY, VNY, and FBY), except HI, and significant for several quality traits (i.e., PRO, Fe, $\mathrm{Zn}$, and $\mathrm{P}$ ). $\mathrm{G} \times \mathrm{E}$ interaction effects were significant for all traits except root PRO and Fe content (Table 3).

The mean performance of the 26 yam bean accessions across environments (Table 4) revealed large and significant variations for all traits among accessions. For several accessions, high SRFYs were observed, such as 209017 with $31.8 \mathrm{~kg} \cdot \mathrm{m}^{-2}$. Accessions 209055 and 209060 combined high values for SRFY, PRO, Fe, and $\mathrm{Zn}$. Accession 209006 had the lowest SRFY (2.2 $\left.\mathrm{kg} \cdot \mathrm{m}^{-2}\right)$, SRDY $\left(0.4 \mathrm{~kg} \cdot \mathrm{m}^{-2}\right)$, and FBY $(2.5$ $\left.\mathrm{kg} \cdot \mathrm{m}^{-2}\right)$. The SRDM content across all accessions was $15.3 \%$ [range of $9.9 \%$ (209050) to $20.5 \%$ (209061)], which is low compared with other root crops, such as cassava (Akinwale et al., 2010; Tumuhimbise et al., 2014). In contrast, other root quality values were high in most accessions and varied widely, with ranges of $8.1 \%$ to $10.8 \% \mathrm{PRO}, 36.5 \%$ to $63.1 \%$ STA, $13.6-31.8 \mathrm{mg} \cdot \mathrm{kg}^{-1} \mathrm{Fe}, 10.3$ $16.7 \mathrm{mg} \cdot \mathrm{kg}^{-1} \mathrm{Zn}, 558-1430 \mathrm{mg} / 100 \mathrm{~g} \mathrm{~K}$, and $160-260 \mathrm{mg} / 100 \mathrm{~g}$ P. The highest PRO, STA, $\mathrm{Fe}, \mathrm{Zn}, \mathrm{K}$, and $\mathrm{P}$ contents were for accessions 209051, 209061, 209049, and 209047. The least performing accession concerning several root quality traits was 209031: PRO (8.1\%), Fe (13.6 mg.kg $\left.{ }^{-1}\right), \mathrm{Zn}\left(10.3 \mathrm{mg} \cdot \mathrm{kg}^{-1}\right)$, and $\mathrm{P}(160 \mathrm{mg} / 100 \mathrm{~g})$. In general, mean values for root quality traits, such as PRO, $\mathrm{Fe}$, and $\mathrm{Zn}$ content of $9.6 \%, 22.8 \mathrm{mg} \cdot \mathrm{kg}^{-1}$, and $12.4 \mathrm{mg} \cdot \mathrm{kg}^{-1}$, respectively (Table 4 ), were remarkable for a root crop.

In an ANOVA in which all factors $(\mathrm{G}, \mathrm{L}$, and $\mathrm{S}$ ) were random and variance components were estimated (Table 5) the $\sigma_{G}^{2}$ for yield traits was significant, except for $\mathrm{HI}$ and $\mathrm{K}$. The magnitude of $\sigma_{G}^{2}$ was large for yield traits, SRFY $\left(52.7 \mathrm{~kg}^{2} \cdot \mathrm{m}^{-2}\right)$ and FBY $(75.3$ $\mathrm{kg}^{2} \cdot \mathrm{m}^{-2}$ ), and small to medium for SRDY $\left(0.48 \mathrm{~kg}^{2} \cdot \mathrm{m}^{-2}\right)$ and VNY $\left(3.1 \mathrm{~kg}^{2} \cdot \mathrm{m}^{-2}\right)$. With respect to significant $\sigma_{G}^{2}$ of quality traits, there was large variation for STA $\left(40.2 \%{ }^{2}\right)$, and medium to large for SRDM $\left(9.3 \%^{2}\right)$ and Fe $\left(16.7 \mathrm{mg}^{2} \cdot \mathrm{kg}^{-2}\right)$. For all traits, $\sigma_{\mathrm{G} \times \mathrm{S}}^{2}$ was not significant except for root $\mathrm{P}$ content, while $\sigma_{\mathrm{G} \times \mathrm{L}}^{2}$ was significant for SRDM and HI. The $\sigma^{2}{ }_{\mathrm{G} \times \mathrm{S} \times \mathrm{L}}$ was significant for yield traits (i.e., SRFY, HI, VNY, and FBY), but not for quality traits, except for root $\mathrm{K}$ content. The estimated ratios of $\sigma_{\mathrm{G}}^{2}: \quad \sigma_{\mathrm{G} \times \mathrm{S}}^{2}: \sigma_{\mathrm{G} \times \mathrm{L}}^{2}: \sigma_{\mathrm{G} \times \mathrm{S} \times \mathrm{L}}: \sigma_{\varepsilon}^{2}$ were 1:0.05:0.09:0.53:1.23, 1:-0.06:-0.11: $0.58: 1.08,1: 0.38: 0.10: 0.52: 2.73$, and 1:-0.71:-0.52:2.42:1.61 for SRFY, FBY, SRDY, and VNY, respectively. These ratios were 1: 0.19:-0.23: 0.66: 0.28, 1: 0.06: 0.36: $0.02: 0.47$ and $1:-0.25:-0.25:-1.08: 0: 7.55$ for STA, SRDM, and Fe, respectively. The ratios of variance components are only given for traits with significant $\sigma_{\mathrm{G}}^{2}$. For SRFY and FBY, a combination of large $\sigma^{2}$ and relatively low $\sigma_{\mathrm{G} \times \mathrm{S}}^{2}, \sigma_{\mathrm{G} \times \mathrm{L}}^{2}$, and $\sigma_{\mathrm{G} \times \mathrm{S} \times \mathrm{L}}^{2}$ was

Table 4. Mean performance of yam bean genotypes for observed traits across seasons and locations.

\begin{tabular}{|c|c|c|c|c|c|c|c|c|c|c|c|c|}
\hline \multirow[b]{2}{*}{ Genotype } & \multicolumn{5}{|c|}{ Yield components $^{z y}$} & \multicolumn{7}{|c|}{ Root quality traits ${ }^{\mathrm{yx}}$} \\
\hline & $\begin{array}{c}\text { SRFY } \\
\left(\mathrm{kg} \cdot \mathrm{m}^{-2}\right)\end{array}$ & $\begin{array}{c}\text { SRDY } \\
\left(\mathrm{kg} \cdot \mathrm{m}^{-2}\right)\end{array}$ & $\begin{array}{c}\mathrm{VNY} \\
\left(\mathrm{kg} \cdot \mathrm{m}^{-2}\right)\end{array}$ & $\begin{array}{c}\text { FBY } \\
\left(\mathrm{kg} \cdot \mathrm{m}^{-2}\right)\end{array}$ & HI (\%) & SRDM (\%) & PRO (\%) & STA $(\%)$ & $\mathrm{Fe}\left(\mathrm{mg} \cdot \mathrm{kg}^{-1}\right)$ & $\mathrm{Zn}\left(\mathrm{mg} \cdot \mathrm{kg}^{-1}\right)$ & $\mathrm{K}(\mathrm{mg} / 100 \mathrm{~g})$ & $\mathrm{P}(\mathrm{mg} / 100 \mathrm{~g})$ \\
\hline 209004 & 3.2 & 0.6 & 2.6 & 5.8 & 73.7 & 18.4 & 10.0 & 60.3 & 23.2 & 13.5 & 987 & 235 \\
\hline 209006 & 2.2 & 0.4 & 0.3 & 2.5 & 82.8 & 16.1 & 9.5 & 55.8 & 23.3 & 11.6 & 828 & 205 \\
\hline 209007 & 6.3 & 1.1 & 1.1 & 7.4 & 67.1 & 20.0 & 10.4 & 51.0 & 25.5 & 13.1 & 1,024 & 234 \\
\hline 209016 & 25.6 & 2.9 & 3.8 & 29.4 & 79.5 & 11.4 & 9.8 & 43.2 & 31.1 & 11.0 & 1,176 & 230 \\
\hline 209017 & 31.8 & 3.4 & 3.9 & 35.7 & 87.2 & 11.5 & 9.4 & 40.5 & 22.0 & 11.2 & 1,339 & 225 \\
\hline 209018 & 18.7 & 1.9 & 4.7 & 23.4 & 71.4 & 14.7 & 9.5 & 43.5 & 16.5 & 11.4 & 1,263 & 217 \\
\hline 209019 & 17.5 & 2.0 & 1.8 & 19.3 & 91.2 & 11.4 & 8.8 & 47.1 & 20.9 & 10.9 & 1,114 & 196 \\
\hline 209023 & 6.4 & 1.1 & 1.8 & 8.2 & 83.1 & 16.9 & 9.9 & 57.7 & 17.8 & 12.4 & 652 & 224 \\
\hline 209025 & 3.8 & 0.7 & 0.4 & 4.2 & 84.2 & 18.3 & 8.2 & 55.1 & 15.9 & 10.9 & 617 & 170 \\
\hline 209027 & 2.9 & 0.5 & 0.2 & 3.1 & 86.0 & 17.2 & 8.9 & 58.3 & 21.5 & 12.6 & 715 & 201 \\
\hline 209028 & 3.9 & 0.6 & 2.0 & 5.9 & 75.4 & 15.5 & 9.7 & 52.3 & 19.5 & 11.4 & 790 & 219 \\
\hline 209031 & 5.4 & 1.1 & 2.0 & 7.4 & 71.5 & 19.2 & 8.1 & 59.3 & 13.6 & 10.3 & 763 & 160 \\
\hline 209033 & 3.7 & 0.8 & 0.9 & 4.6 & 74.0 & 19.7 & 10.5 & 57.6 & 23.4 & 13.6 & 880 & 217 \\
\hline 209034 & 8.3 & 1.5 & 5.8 & 13.9 & 70.8 & 19.7 & 9.3 & 61.4 & 13.9 & 13.1 & 558 & 179 \\
\hline 209046 & 15.0 & 1.6 & 4.2 & 19.3 & 77.1 & 12.5 & 10.0 & 47.3 & 29.7 & 12.9 & 1,467 & 253 \\
\hline 209047 & 27.1 & 3.3 & 3.3 & 31.1 & 82.6 & 12.0 & 9.6 & 47.4 & 26.6 & 12.0 & 1,124 & 223 \\
\hline 209048 & 18.3 & 2.4 & 3.1 & 21.4 & 86.2 & 12.8 & 9.4 & 52.0 & 25.0 & 12.4 & 837 & 236 \\
\hline 209049 & 15.0 & 1.6 & 1.7 & 16.7 & 89.3 & 11.5 & 10.2 & 41.0 & 31.8 & 12.6 & 1,269 & 260 \\
\hline 209050 & 17.9 & 1.8 & 5.0 & 22.9 & 75.7 & 10.7 & 9.9 & 36.5 & 23.2 & 11.3 & 1,163 & 229 \\
\hline 209051 & 22.4 & 2.4 & 4.8 & 27.2 & 80.2 & 11.0 & 10.8 & 39.2 & 26.0 & 13.2 & 1,430 & 254 \\
\hline 209052 & 14.7 & 1.5 & 2.6 & 17.3 & 83.0 & 9.9 & 9.7 & 43.1 & 27.5 & 11.2 & 1,081 & 242 \\
\hline 209055 & 20.9 & 3.5 & 4.6 & 25.5 & 82.8 & 16.8 & 10.3 & 59.3 & 24.3 & 14.4 & 989 & 236 \\
\hline 209057 & 9.0 & 1.4 & 6.6 & 18.0 & 54.3 & 15.1 & 8.7 & 49.6 & 20.2 & 12.1 & 755 & 231 \\
\hline 209058 & 10.1 & 2.0 & 2.7 & 12.8 & 76.5 & 18.8 & 9.9 & 54.1 & 21.9 & 14.1 & 971 & 213 \\
\hline 209060 & 16.1 & 2.5 & 5.2 & 21.4 & 74.4 & 15.1 & 9.2 & 57.7 & 21.3 & 13.3 & 1,076 & 212 \\
\hline 209061 & 6.8 & 1.3 & 6.9 & 13.7 & 46.5 & 20.5 & 10.8 & 63.1 & 28.7 & 16.7 & 952 & 234 \\
\hline $\begin{array}{r}\text { Overall } \\
\text { Mean }\end{array}$ & 12.8 & 1.7 & 3.2 & 16.1 & 77.2 & 15.3 & 9.6 & 51.3 & 22.9 & 12.4 & 993 & 220 \\
\hline $\operatorname{LSD}^{\mathrm{w}}$ & 11.8 & 1.7 & 3.5 & 12.7 & 25.2 & 2.8 & 2.1 & 14.4 & 8.8 & 3.4 & 556 & 74 \\
\hline
\end{tabular}

${ }^{\mathrm{z}} \mathrm{SRFY}=$ storage root fresh yield; SRDY = storage root dry yield; VNY = vine yields; FBY = fresh biomass yield; HI = harvest index.

${ }^{\mathrm{y}}$ On a fresh weight basis.

${ }^{\mathrm{x}} \mathrm{SRDM}=$ storage root dry matter content $\mathrm{PRO}=$ root protein content; $\mathrm{STA}=$ root starch $\operatorname{content} ; \mathrm{Fe}=$ root iron content; $\mathrm{Zn}=$ root $\mathrm{zinc}$ content; $\mathrm{K}=$ root potassium content; $\mathrm{P}=$ root phosphorus content.

${ }^{w_{L}}$ DS, least significant difference at $P<0.05$ with all factors considered as fixed except replication. 
Table 5. Variance components, phenotypic and genetic coefficients of variation, and broad sense heritability of 12 observed traits in yam beans.

\begin{tabular}{|c|c|c|c|c|c|c|c|c|}
\hline \multirow[b]{2}{*}{ Traits } & \multicolumn{5}{|c|}{ Variance components } & \multirow[b]{2}{*}{$\mathrm{GCV}^{\mathrm{z}}(\%)$} & \multirow[b]{2}{*}{$\operatorname{PCV}^{y}(\%)$} & \multirow[b]{2}{*}{$\mathrm{H}^{2 \mathrm{x}}$} \\
\hline & $\sigma_{G}^{2}$ & $\sigma_{G \times S}^{2}$ & $\sigma_{\mathrm{G} \times \mathrm{L}}^{2}$ & $\sigma_{\mathrm{G} \times \mathrm{S} \times \mathrm{L}}^{2}$ & $\sigma_{\varepsilon}^{2}$ & & & \\
\hline Storage root fresh yield, $\mathrm{kg}^{2} \cdot \mathrm{m}^{-2}$ & $52.7 * *$ & 2.5 & 4.8 & $27.7 *$ & 64.8 & 56.7 & 66.0 & 73.8 \\
\hline Storage root dry matter, $\%^{2}$ & $9.3 * *$ & 0.7 & $3.3 * *$ & 0.2 & 4.4 & 20.0 & 22.6 & 78.4 \\
\hline Storage root dry yield, $\mathrm{kg}^{2} \cdot \mathrm{m}^{-2}$ & $0.48 *$ & 0.18 & 0.05 & 0.25 & 1.31 & 40.8 & 53.3 & 58.4 \\
\hline Harvest index, $\%{ }^{2}$ & 55.4 & 13.9 & $163.7 *$ & $163.0 * *$ & 219.3 & 9.64 & 17.9 & 28.9 \\
\hline Vine yield, $\mathrm{kg}^{2} \cdot \mathrm{m}^{-2}$ & $3.1 * *$ & -2.1 & -1.6 & $7.5 * *$ & 5.0 & 55.0 & 60.5 & 82.7 \\
\hline Fresh biomass yield, $\mathrm{kg}^{2} \cdot \mathrm{m}^{-2}$ & $75.3 * *$ & -4.5 & -8.2 & $44.0 * *$ & 81.3 & 53.9 & 59.0 & 83.6 \\
\hline Protein content, $\%^{2} \mathrm{DM}^{\mathrm{w}}$ & 0.06 & 0.42 & 0.08 & 0 & 2.4 & 2.6 & 8.1 & 9.8 \\
\hline Starch content of roots, $\%^{2} \mathrm{DM}$ & $40.2^{*}$ & 7.7 & -9.2 & 26.5 & 111.4 & 12.4 & 15.1 & 67.0 \\
\hline Iron content of roots, $\mathrm{mg}^{2} \cdot \mathrm{kg}^{-2} \mathrm{DM}$ & $16.7 *$ & -4.1 & -4.1 & -18.1 & 126.2 & 17.8 & 21.3 & 70.0 \\
\hline Zinc content of roots, $\mathrm{mg}^{2} \cdot \mathrm{kg}^{-2} \mathrm{DM}$ & 0.29 & 1.24 & 0.52 & 0.44 & 5.19 & 4.3 & 11.20 & 15.0 \\
\hline Potassium content of roots, $\mathrm{mg}^{2} \cdot \mathrm{kg}^{-2} \mathrm{DM}$ & 29,453 & 9,928 & $-9,016$ & $64,966^{* *}$ & 122,158 & 17.3 & 25.0 & 48.0 \\
\hline Phosphorus content of roots, $\mathrm{mg}^{2} \cdot \mathrm{kg}^{-2} \mathrm{DM}$ & 403 & $886^{*}$ & 459 & -50 & 3,052 & 9.1 & 17.2 & 27.9 \\
\hline
\end{tabular}

${ }^{\mathrm{z}}$ Genotypic CV.

yphenotypic CV.

${ }^{x}$ Broad sense heritability (\%).

*,**Significant at $P<0.05$ and 0.01 , respectively.

$\mathrm{DM}=$ dry matter.

observed $\left(\sigma^{2}{ }_{\mathrm{G} \times \mathrm{S}}, \sigma_{\mathrm{G} \times \mathrm{L}}^{2}\right.$, and $\sigma_{\mathrm{G} \times \mathrm{S} \times \mathrm{L}}$ were less than $\left.\sigma_{\mathrm{G}}^{2}\right)$. The quality traits, STA, SRDM, and $\mathrm{Fe}$, exhibited medium to large $\sigma^{2}{ }_{G}$ combined with relatively low $\sigma_{G \times S}^{2}$, $\sigma_{\mathrm{G} \times \mathrm{L}}^{2}$, and $\sigma_{\mathrm{G} \times \mathrm{S} \times \mathrm{L}}$. For Fe content of storage roots, error was high $\left(\sigma_{\varepsilon}^{2} / \sigma_{\mathrm{G}}^{2}=7.56\right)$, whereas for all other traits with significant $\sigma_{G}^{2}$, the $\sigma_{\varepsilon}^{2}$ was relatively low $\left(\sigma_{\varepsilon}^{2} / \sigma_{G}^{2}<3\right)$.

There were high estimates of GCV for SFRY (56.7\%), VNY (55\%), FBY (53.9\%), and SRDY (40.8\%); whereas there were medium to high values for STA $(12.4 \%)$, SRDM (20\%), and Fe content (17.8\%) among others (Table 5). Similarly, PCV was high for SRFY $(66 \%)$, VNY $(60 \%)$, FBY $(59 \%)$, and SRDY (53.3\%); and medium to high for STA $(15.1 \%)$, SRDM $(22.6 \%)$, and $\mathrm{Fe}(21.3 \%)$. In addition, $\mathrm{H}^{2}$ estimates for yield traits were high $(>50 \%)$ for SRFY, SRDY, VNY, and FBY, and only low $(<30 \%)$ for HI. For quality traits, $\mathrm{H}^{2}$ was high for SRDM (78.4\%), Fe (70\%), and STA $(67 \%)$; medium for $\mathrm{K}$ content $(48 \%)$; and low for the remaining quality traits $(<30 \%)$.

Phenotypic correlation coefficients for yield components and nutritional quality traits are presented in Table 6 . There were strong and significant $(P<0.001)$ positive correlations between SRFY and both SRDY $(r=0.926)$ and FBY $(r=0.962)$, as well as between SRDY and FBY $(r=0.899)$. Correlations between FBY and VNY were moderate $(r=0.552)$. SRFY showed weak but significant negative correlations with SRDM $(r=-0.423)$ and STA $(r=-0.314)$. For PRO, there were significant moderate to strong correlations with $\mathrm{Fe}(r=0.499), \mathrm{P}(r=$ $0.700)$, and $\mathrm{Zn}(r=0.756)$ contents. Moreover, root Fe content was positively correlated with root $\mathrm{Zn}$ content $(r=0.754)$ and with $\mathrm{P}$ content $(r=0.648)$.

\section{Discussion}

The yam bean germplasm tested in this study was shown to be genetically variable and so the crop appears to have potential for Uganda and countries with similar agroecologies to Namulonge and Serere in East or Central Africa. These two locations represent important areas for growing root crops in Uganda. Across both locations and seasons, there was a mean root yield for yam bean germplasm of $12.8 \mathrm{~kg} \cdot \mathrm{m}^{-2}$ for SRFY with yields up to $31.8 \mathrm{~kg} \cdot \mathrm{m}^{-2}$ (P. erosus accession 209017) (Table 4). However, the overall germplasm mean of root dry matter was low with $15.3 \%$ for SRDM and a dry matter content of up to $20.5 \%$ ( $P$. tuberosus accession 209061). This was associated with considerable VNY and biomass production, with germplasm mean for FBY of $16.1 \mathrm{~kg} \cdot \mathrm{m}^{-2}$ and up to $35.7 \mathrm{~kg} \cdot \mathrm{m}^{-2} \mathrm{FBY}$ for $P$. erosus accession 209017. Yam bean with low SRDM might be as attractive to farmers and consumers in Uganda as it is in Central American and Asian countries, thus two or three accessions of the germplasm could be disseminated in Uganda for use as a root/fruit crop. However, to reduce the risks of failure of such dissemination efforts, further yield, and adaptation trials are required. Our results only indicate that the crop is adapted to both important root crop growing areas in Uganda: Namulonge and Serere. For all yield traits, significant environmental main effects were observed except for $\mathrm{HI}$ and $\mathrm{K}$ content $(\mathrm{Ta}$ ble 3 ). The yam bean germplasm results indicated that contrasting locations and environments were used in our study.

Significant genotypic differences suggest substantial and exploitable genetic variation among these yam bean accessions (Tables 3 and 4). The accessions represent a broad range of yam bean genotypes with very diverse geographical origins (Table 1) and we assume different adaptation potentials for this germplasm in environments of East and Central Africa. This is the first study on yam bean germplasm in Uganda, and to the best of our knowledge, it is also the first evaluating all three cultivated yam bean species together to estimate variance components and derived parameters such as heritabilities and correlations in the yam bean genepool. Evaluating all cultivated yam bean species together was useful because all three species can be easily crossed to produce fertile hybrids. It can be argued that different species should be evaluated in separate trials as performed by
Zanklan et al. (2007). However, it has been repeatedly reported that $P$. erosus, $P$. ahipa, and $P$. tuberosus are very closely related (Santayana et al., 2014; Sørensen, 1996; Zanklan et al., 2007). It is noteworthy that the closest related major crop is considered to be soybean (Ingham, 1990; Lackey, 1977). The CIP, from which the germplasm of this study was obtained, has generated a set of $3 \times$ 3 P. erosus $\times P$. tuberosus type chuin cross population as well as a set of $3 \times 3 P$. ahipa $\times$ $P$. tuberosus type chuin cross populations, which are all vigorous and fertile (B. Heider, personal communication). Originally, we planned to evaluate the 26 yam bean accessions of our study together with $18 \mathrm{~F}_{1}$ interspecific hybrid accessions, but these hybrids were not available, because they are derivatives of chuin accessions and these are protected under national rights of Peru. Certainly including chuin and its derivatives would have altered the results of the present study concerning SRDM. However, this would not have greatly affected results for other traits because five $P$. tuberosus accessions were included (Table 1).

The genetic variation in the yam bean genepool for yield traits is remarkably large, except for $\mathrm{HI}$ and $\mathrm{K}$ and $\mathrm{P}$ contents for which no significant $\sigma_{G}^{2}$ was observed (Table 5). The SRFY germplasm mean of $12.8 \mathrm{~kg} \cdot \mathrm{m}^{-2}$ (Table 4) in our study was associated with $\sigma_{G}^{2}$ of $52.7 \mathrm{~kg} \cdot \mathrm{m}^{-2}$, and the SRDM germplasm mean of $15.3 \%$ (Table 4 ) with $\sigma_{G}^{2}$ of $9.3 \%{ }^{2}$ (Table 5). The germplasm mean of $1.7 \mathrm{~kg} \cdot \mathrm{m}^{-2}$ SRDY (Table 4) was associated with significant $\sigma_{G}^{2}$ of $0.48 \mathrm{~kg} \cdot \mathrm{m}^{-2}$ (Table 5). The heritabilities for yield traits were high, except for HI (Table 5). For this reason, a genetic improvement in $\sqrt{\sigma_{G}^{2}}$ might be feasible after one recombination and selection step for yield traits in yam beans, which corresponds to a genetic gain of $7.3 \mathrm{~kg} \cdot \mathrm{m}^{-2}$ SRFY or 0.7 $\mathrm{kg} \cdot \mathrm{m}^{-2}$ SRDY using the germplasm mean as the base line. Interestingly, HI does not appear to be a trait to select indirectly for higher root yields in yam bean; however, such a statement might not hold true for seed yield in yam bean, which was not investigated in the present study. This appears to 
differ for yam beans compared with other root crops such as sweetpotato, where HI merits consideration for indirect selection of higher root yields (Andrade et al., 2016; Grüneberg et al., 2005; Tumwegamire et al., 2011). The variation in storage root yield observed in this study is consistent with findings from contrasting locations in Benin, West Africa (Zanklan et al., 2007) and the mean values are similar or slightly lower than values reported in Sierra Leone (Belford et al., 2001). They also compare closely with traditional root crops such as cassava for which average yield in Uganda is estimated as $12.0 \mathrm{t} \cdot \mathrm{ha}^{-1}$ (FAOSTAT, 2013) and 16.8 t.ha ${ }^{-1}$ (Tumuhimbise et al., 2014); however, it should be noted that yam bean can be grown at many locations in Uganda twice per year and cassava only once. The genetic variation for yield traits relative to the population mean, estimated using GCV (Table 5), was large $(>30 \%)$ for most yield traits (i.e., SRFY, SRDY, VNY, and FBY), medium for SRDM $(>10 \%$ and $<30 \%)$, and low for $\mathrm{HI}(<10 \%)$. The importance of environmental influence on these traits as revealed by several high PCV estimates ( $>30 \%$, Table 5$)$ indicated that considerable variation should be expected in field observations, but we assume that accessions differ in their yield stability and this should be considered for initiating official variety release trials and seed dissemination in Uganda. It is noteworthy that small differences between GCV and PCV values reveal high genetic determination of observed phenotypic variation (Akinwale et al., 2010) and these should be associated with medium to high GCV and PCV estimates to merit breeding efforts. This was observed for all yield related traits (i.e., SFRY, VNY, FBY, SRDM, and SRDY), except for HI, in the yam bean germplasm in Uganda.

Yam beans in the Americas and Asia are usually consumed raw. However, for Africa, there is currently still no market for such a use, but processed yam beans give sufficient economic returns to farmers (Adegbola et al., 2015; Padonou et al., 2013). We are not certain if low SRDM content makes yam bean less attractive to farmers in Africa as previously predicted (Grüneberg et al., 2003; Zanklan et al., 2007). Certainly, farmers prefer high conversion rates in processing dry-based stable food products, such as gari (Padonou et al., 2013). However, it has been shown that the juice obtained in processing gari and other products from low dry matter yam beans in Benin is very attractive in taste and value for further processing into bottle refreshments, yogurt, and even alcohol (W. Padonou, personal communication). The Institut National de Recherche Agronomique $\mathrm{du}$ Benin has intensively studied processing and marketing strategies for yam beans and has disseminated the crop to farmers, achieving an adoption rate of $47 \%$ across six agroecological zones of Benin (Adegbola et al., 2015; Grüneberg, 2016; Padonou et al., 2013). We consider this to indicate that it is possible to sustainably introduce yam bean into Africa even though only low to medium dry matter yam beans are currently available. It could be that the issue of SRDM in yam beans and the expectation that low dry matter yam beans will not meet farmer and consumer preferences in Africa was overestimated. With respect to SRDM, germplasm mean values observed in our study for Serere $(17.1 \%$ and $17.3 \%$ in seasons 1 and 2 , respectively) strikingly corresponded to observations for $P$. erosus accessions (germplasm SRDM mean estimates of $17.4 \%$ across 14 accessions) at Songhai in Benin (Zanklan et al., 2007) - it may be that Serere and Songhai have similar agroecologies. It is certainly a limitation of our study that no $P$. tuberosus chuin accessions known for SRDM of up to $36 \%$ (Grüneberg et al., 2003; Sørensen, 1996; Zanklan et al., 2007) could be used, because negotiations with Peruvian authorities to allow exportation of these accessions or derivatives were ongoing during this study. However, this limitation has one advantage. Owing to our $\sigma_{G}^{2}$ estimate with the magnitude of $9.3 \%{ }^{2}$ SRDM (Table 5) in exclusively low dry matter germplasm we propose a new hypothesis: "it is possible to develop high dry matter yam beans from low dry matter yam beans." One drawback is that this might take longer compared with the use of high SRDM chuin accessions as parents. As a "rule of thumb," we assume that a genetic gain of around $\sqrt{\sigma_{G}^{2}}$ (which corresponds in our study to $3.0 \%$ SRDM) is possible for SRDM per recurrent selection cycle, provided that population size is large $(>300$ entries) and the selection fraction is $5 \%$ to $10 \%$. Thus, it should be possible to develop high dry matter yam beans without using chuin genetic resources and so avoid the problem of their lack of availability.

As expected, our study confirmed that yam bean is a starchy root crop with elevated protein contents. We observed a germplasm mean of $51.3 \%$ STA and $9.6 \%$ PRO on dry weight basis with up to $63 \%$ and $10.8 \%$, respectively (Table 4; STA: P. tuberosus accession 209061, PRO: P. erosus accession 209051, and $P$. tuberosus accession 209061). This was associated with significant $\sigma_{G}^{2}$ for STA of $40.2 \%{ }^{2}$ (Table 5) but there was no significant $\sigma_{G}^{2}$ for PRO, $\mathrm{K}$, and $\mathrm{P}$ in yam bean germplasm. The STA contents correspond to other root crops, such as sweetpotato (Tumwegamire et al., 2011) and cassava (Tumuhimbise et al., 2014), whereas PRO level was about twice that in conventional root crops. Moreover, the contents of Fe, $\mathrm{Zn}$, $\mathrm{K}$, and $\mathrm{P}$ in yam bean storage roots were interesting in the present study with germplasm means estimated as $22.9 \mathrm{mg} \cdot \mathrm{kg}^{-1}, 12.4$ $\mathrm{mg} \cdot \mathrm{kg}^{-1}, 993 \mathrm{mg} / 100 \mathrm{~g}$, and $220 \mathrm{mg} / 100 \mathrm{~g}$ on a dry weight basis, respectively (Table 4). The recommended daily intakes of these nutrients for adults are $8 \mathrm{mg}$ (male) and $18 \mathrm{mg}$ (female) of Fe, about $9 \mathrm{mg}$ of $\mathrm{Zn}, 4.7$ $\mathrm{g}$ of $\mathrm{K}$, and $700 \mathrm{mg}$ of $\mathrm{P}$ (National Academy of Sciences, 2004). On a fresh weight basis (assuming 15\% SRDM), we estimate that 200 $\mathrm{g}$ of fresh yam bean roots contain $0.7 \mathrm{mg}$ of $\mathrm{Fe}, 0.4 \mathrm{mg}$ of $\mathrm{Zn}, 0.3 \mathrm{~g}$ of $\mathrm{K}$, and $66 \mathrm{mg}$ of $\mathrm{P}$. An amount of $200 \mathrm{~g}$ of fresh roots of low dry matter yam beans can be easily eaten as snack, which should provide 5-10\%, 5\%, $5 \%$, and $10 \%$ of the recommended daily intake for adults of $\mathrm{Fe}, \mathrm{Zn}, \mathrm{K}$, and $\mathrm{P}$, respectively. It should be noted that we observed significant $\sigma_{G}^{2}$ for $\mathrm{Fe}$ with a magnitude of $16.7 \mathrm{mg}^{2} \cdot \mathrm{kg}^{-2}$, relatively high $\mathrm{H}^{2}$, medium

Table 6. Phenotypic correlations calculated as means across seasons, locations, and replications among yield and quality traits of yam bean ( $\mathrm{N}=26)$.

\begin{tabular}{|c|c|c|c|c|c|c|c|c|c|c|c|}
\hline \multicolumn{11}{|c|}{ Yield components and quality traits } & \multirow[b]{2}{*}{$\mathrm{K}^{\mathrm{yx}}$} \\
\hline & $\mathrm{SRFY}^{\mathrm{z}}$ & SRDM $^{\mathrm{y}}$ & SRDY $^{\mathrm{z}}$ & $\mathrm{VNY}^{\mathrm{z}}$ & $\mathrm{FBY}^{\mathrm{z}}$ & $\mathrm{HI}^{\mathrm{z}}$ & $\mathrm{PRO}^{\mathrm{yx}}$ & $\mathrm{STA}^{\mathrm{yx}}$ & $\mathrm{Fe}^{\mathrm{yx}}$ & $\mathrm{Zn}^{\mathrm{yx}}$ & \\
\hline SRDM & $-0.423 *$ & & & & & & & & & & \\
\hline SRDY & $0.926 * * *$ & $-0.206 * * *$ & & & & & & & & & \\
\hline VNY & $0.332 *$ & -0.186 & $0.344 *$ & & & & & & & & \\
\hline FBY & $0.962 * * *$ & $-0.467^{*}$ & $0.899 * * *$ & $0.552 * *$ & & & & & & & \\
\hline HI & 0.280 & -0.072 & 0.252 & $-0.619 * *$ & -0.05 & & & & & & \\
\hline PRO & 0.109 & -0.053 & 0.081 & 0.059 & -0.01 & 0.00 & & & & & \\
\hline STA & $-0.314 *$ & $0.563 * *$ & -0.138 & -0.031 & -0.24 & -0.048 & -0.162 & & & & \\
\hline $\mathrm{Fe}$ & 0.153 & -0.272 & 0.082 & 0.089 & 0.02 & -0.085 & $0.499 *$ & $-0.396 *$ & & & \\
\hline $\mathrm{Zn}$ & -0.022 & -0.247 & $0.489 *$ & 0.127 & -0.04 & -0.095 & $0.756 * * *$ & $0.373^{*}$ & $0.754 * * *$ & & \\
\hline $\mathrm{K}$ & $0.303 *$ & $-0.419 *$ & 0.172 & 0.090 & 0.27 & 0.020 & $0.303 *$ & $-0.667 * *$ & 0.229 & 0.062 & \\
\hline$\underline{P}$ & 0.202 & -0.258 & 0.140 & 0.182 & 0.03 & -0.071 & $0.700 * * *$ & -0.259 & $0.648 * *$ & $0.416^{*}$ & 0.276 \\
\hline
\end{tabular}

${ }^{\mathrm{z}}$ Yield components: FSRY $=$ fresh root yield $\left(\mathrm{kg} \cdot \mathrm{m}^{-2}\right) ; \mathrm{SRDY}=$ root dry yield $\left(\mathrm{kg} \cdot \mathrm{m}^{-2}\right) ; \mathrm{VNY}=$ vine yield $\left(\mathrm{kg} \cdot \mathrm{m}^{-2}\right) ; \mathrm{FBY}=$ fresh biomass yield $\left(\mathrm{kg} \cdot \mathrm{m}^{-2}\right) ; \mathrm{HI}=$ harvest index.

${ }^{\mathrm{y}}$ Root quality traits: $\mathrm{SRDM}=$ root dry matter content $(\%) ; \mathrm{PRO}=\operatorname{root}$ protein content $(\%) ; \mathrm{STA}=\operatorname{root}$ starch content $(\%) ; \mathrm{Fe}=$ root iron content $\left(\mathrm{mg} \cdot \mathrm{kg}{ }^{-1}\right) ; \mathrm{Zn}=$ root zinc content $\left(\mathrm{mg} \cdot \mathrm{kg}^{-1}\right) ; \mathrm{K}=$ root potassium content $\left(\mathrm{mg} \cdot \mathrm{kg}^{-1}\right) ; \mathrm{P}=$ root phosphorus content $\left(\mathrm{mg} \cdot \mathrm{kg}^{-1}\right)$.

${ }^{\mathrm{x}}$ On a dry matter basis.

$*, * *, * * *$ Significant at $P \leq 0.05,0.01$, or 0.001 , respectively. 
GCV and PCV, and small differences between GCV and PCV (Table 5), thus we conclude that it is possible to obtain genetic gains for root $\mathrm{Fe}$ in yam bean. However, there is not much room for genetic improvement for PRO, $\mathrm{Zn}, \mathrm{K}$, and P because $\sigma_{G}^{2}$ was not significant, GCVs were low $(<10 \%)$, or differences between GCV and PCV were relatively large. Selection for $\mathrm{PRO}, \mathrm{Zn}, \mathrm{K}$, and $\mathrm{P}$ contents using yam bean germplasm available in Uganda may not be effective unless further germplasm is found or introduced and, with respect to quality traits, breeding should focus on SRDM, STA, and perhaps $\mathrm{Fe}$. The yam bean germplasm observed mean Fe content of $22.9 \mathrm{mg} \cdot \mathrm{kg}^{-1}$ (Table 4) was not as large as expected considering the studies of Kale (2006) who reported Fe contents up to $130 \mathrm{mg} \cdot \mathrm{kg}^{-1}$ in the yam bean samples as also reported by Zanklan et al. (2007) and Padonou et al. (2013). However, we estimated root $\mathrm{Fe}$ content across location and seasons of up to $31.8 \mathrm{mg} \cdot \mathrm{kg}^{-1}$ ( $P$. erosus accession 209049; Table 4). Several authors have reported root $\mathrm{Fe}$ contents similar or marginally higher than we observed (Dini et al., 2013; Doporto et al., 2011; Heider et al., 2011; Santayana et al., 2014). There are often issues with estimates of plant Fe due to nonplant Fe contamination of samples. However, the NIRS method we used to estimate root Fe was calibrated in Peru with yam bean storage root samples analyzed by inductively coupled plasma argon optical emission spectrometer (ICP-OES) and shown to have no nonplant $\mathrm{Fe}$ contamination by aluminum content estimates of samples (required to be close to zero). The highest estimates for root Fe contents in yam bean across Peruvian environments using ICP-OES were 23.5 $\mathrm{mg} \cdot \mathrm{kg}^{-1}$ in $P$. erosus and $52.0 \mathrm{mg} \cdot \mathrm{kg}^{-1}$ in $P$. tuberosus on a dry weight basis (R. Carpio, personal communication). The Fe levels in yam bean storage roots and especially $\mathrm{Fe}$ bioavailability merits further research. Yam beans show higher Fe storage root contents compared with other root crops such as sweetpotato, with a germplasm mean of $21.6 \mathrm{mg} \cdot \mathrm{kg}^{-1}$ (Tumwegamire et al., 2011). Concerning the critical question of whether $\mathrm{Fe}$ of yam beans is bioavailable there is only preliminary information indicating high bioavailability (Grüneberg, 2016). Considering nutritional impact and the dimension of $\mathrm{Fe}$ deficiency in the world food supply (Pfeiffer and McClafferty, 2007), further studies should prioritize contents of $\mathrm{Fe}$ in yam bean storage roots and $\mathrm{Fe}$ bioavailability (bioavailability is the multiplication factor for Fe uptake and nutritional value in food). Such studies should include processed products because they could be more Fe dense than raw roots.

Correlation analysis indicated the possibility of simultaneously selecting SRFY, SRDY, and FBY (Table 6). Because of the negative correlation between SRFY and SRDM, breeding aiming at medium to high SRDM in yam beans should consider both traits in yield evaluations (e.g., by using SRDY information). Selection for SRDY or
FBY would lead indirectly to positive genetic gains in SRFY. The strong positive correlation $(r=0.563)$ between SRDM and STA suggests that starch constitutes a large proportion of SRDM content in yam beans. The challenge for breeding, however, is simultaneous improvement of SRFY and SRDM as well as STA ( $r=-0.423$ and -0.314 , respectively). Yam bean accessions with higher yields tended to have lower storage root dry matter and STA contents and therefore different tastes, which would be easily observable in taste panel studies. This means dry matter and STA contents will be compromised as storage root size and SRFY increase. The trade-off between high SRDM content and the size of yam bean roots is certainly caused by high moisture content of storage roots that leads to low SRDM and STA contents, as well as lower starch yields as observed by Rizky et al. (2013).

In conclusion, yam bean germplasm available in Uganda for breeding should allow genetic gains for fresh storage root yield, root dry matter, dry matter yields, biomass yields, starch content and yield, and root $\mathrm{Fe}$ contents. The desired attributes of these traits can be to a certain extent recombined in genotypes when these attributes appear in different genotypes before selection. HI is not a trait to improve storage root yields in yam bean. An unexpected finding was that it appears possible to breed for high dry matter yam beans by using low dry matter yam beans due to the observed genetic variation among low dry matter yam beans without having access to the high dry matter chuin material. The magnitude of root Fe contents, bioavailability of root $\mathrm{Fe}$, as well as Fe contents and bioavailability of products processed from yam beans merit further research. More information on $\mathrm{Fe}$ in yam bean is required to determine if this trait merits breeding effort.

\section{Literature Cited}

Abinasa, M., A. Ayana, and G. Bultosa. 2011. Genetic variability, heritability and trait associations in durum wheat (Triticum turgidum L. var. durum) genotypes. Afr. J. Agr. Res. 6:3972-3979.

Adegbola, P.Y., A.A. Nestor, P. Houessionon, N. Alokpai, K. Hell, G. Thiele, P. Fandohan, and G.A. Mensah. 2015. Socio-economic analysis of Pachyrhizus erosus cultivation in Benin: Profitability and cost function analysis. Proc. 29th ICAE, 9-14 Aug. 2015, Milan, Italy.

Akinwale, M., B. Akinyele, A. Dixon, and A. Odiyi. 2010. Genetic variability among fortythree cassava genotypes in three agroecological zones of Nigeria. J. Plant Breed. Crop Sci. 2:104-109.

Andrade, M.I., A. Naico, J. Ricardo, R. Eyzaguirre, G.S. Makunde, R. Ortiz, and W.J. Grüneberg. 2016. Genotype $\times$ environment interaction and selection for drought adaptation in sweetpotato (Ipomoea batatas [L.] Lam.) in Mozambique. Euphytica 209:261-280.

Annerose, D. and O. Diouf. 1998. Recherches sur l'adaptation de la culture de pachyrhizus dc. En zones semi-arides. Pachyrhizus. Proc. of the 2nd International Symposium on Tuberous Legumes, 5-8 Aug. 1996, Celaya, Mexico.
Belford, E.J., A.B. Karim, and P. Schröder. 2001. Exploration of the tuber production potential of yam bean (Pachyrhizus erosus (L.) Urban) under field conditions in Sierra Leone. J. Appl. Bot. 75:31-38.

Burton, G.W. and E. Devane. 1953. Estimating heritability in tall fescue (Festuca arundinacea) from replicated clonal material. Agron. J. 45:478-481.

Castellanos, J., F. Zapata, V. Badillo, J. PeñaCabriales, E. Jensen, and E. Heredia-García. 1997. Symbiotic nitrogen fixation and yield of Pachyrhizus erosus (L) urban cultivars and Pachyrhizus ahipa (Wedd) Parodi landraces as affected by flower pruning. Soil Biol. Biochem. 29:973-981.

Delêtre, M., B. Soengas, J. Utge, J. Lambourdière, and M. Sørensen. 2013. Microsatellite markers for the yam bean Pachyrhizus (Fabaceae). Appl. Plant Sci. 1(7).

Dini, C., M.C. Doporto, M.A. García, and S.Z. Viña. 2013. Nutritional profile and anti-nutrient analyses of Pachyrhizus ahipa roots from different accessions. Food Res. Intl. 54:255-261.

Doporto, M.C., A. Mugridge, M.A. García, and S.Z. Viña. 2011. Pachyrhizus ahipa (Wedd.) Parodi roots and flour: Biochemical and functional characteristics. Food Chem. 126:16701678

Falconer, D.S. and T.F. Mackay. 1996. Introduction to quantitative genetics. 4th ed. Longman, Burnt Mill, UK

FAO. 1979. Review on agriculture and development. Conventional crops imperil good protein. Ceres 12:4-5.

FAOSTAT. 2013. May 2015. <http://faostat.fao.org/> Forsyth, J.L., S.G. Ring, T.R. Noel, R. Parker, P. Cairns, K. Findlay, and P.R. Shewry. 2002. Characterization of starch from tubers of yam bean (Pachyrhizus ahipa). J. Agr. Food Chem. 50:361-367.

Forsyth, J.L. and P.R. Shewry. 2002. Characterization of the major proteins of tubers of yam bean (Pachyrhizus ahipa). J. Agr. Food Chem. 50:1939-1944.

Grüneberg, W.J. 2007a. Pre-Proposal: Enhancing the nutrient-rich yam bean (Pachyrhizus spp.) storage root to improve food quality and availability and sustainability of farming systems in Central- and West Africa. <https:// www.researchgate.net/profile/W_Grueneberg/ publications $>$.

Grüneberg, W.J. 2007b. Enhancing the nutrientrich yam bean (Pachyrhizus spp.) storage root to improve food quality and availability and sustainability of farming systems in Centraland West Africa. <https://www.researchgate. net/profile/W_Grueneberg/publications>.

Grüneberg, W.J. 2016. Enhancing the nutrient-rich yam bean (Pachyrhizus spp.) to improve food quality and availability and sustainability of farming systems in Central- and West Africa (Final project report 2015). International Potato Center (CIP), Lima, Peru.

Grüneberg, W.J., P. Freynhagen-Leopold, and O. Delgado-Váquez. 2003. A new yam bean (Pachyrhizus spp.) interspecific hybrid. Genet. Resources Crop Evol. 50:757-766.

Grüneberg, W.J., F.D. Goffman, and L. Velasco. 1999. Characterization of yam bean (Pachyrhizus spp.) seeds as potential sources of high palmitic acid oil. J. Amer. Oil Chem. Soc. 76:1309-1312.

Grüneberg, W.J., K. Manrique, Z. Dapeng, and M. Hermann. 2005. Genotype $\times$ environment interactions for a diverse set of sweet potato clones evaluated across varying ecogeographic conditions in Peru. Crop Sci. 45:2160-2171. 
Gupta, K., G. Talwar, V. Jain, K. Dhawan, and S. Jain. 2003. Salad crops root, bulb, and tuber crops, p. 5060-5073. In: Encyclopedia of Food Science and Nutrition. doi:10.1016/B0-12-227055-X/01040-3.

Heider, B., S. Tumwegamire, P. Tukamuhabwa, J. Ndirigwe, G. Bouwe, A. Bararyenya, K. Hell, J. Leclercq, E. Lautié, and R. Wassens. 2011. Nutritional improvement of yam bean and sustainability of farming systems in central and West Africa. Afr. Crop Sci. 10:93-95.

Hill, J., H.C. Becker, and P.M.A. Tigerstedt. 1998. Quantitative and ecological aspects of plant breeding. $1^{\text {st }}$ ed. Chapman \& Hall, London, UK.

Ingham, J.L. 1990. Systematic aspects of phytoalexin formation within tribe Phaseoleae of the Leguminosae (Subfamily Papilionoideae). Biochem. Syst. Ecol. 18:329-343.

Kale, P.R. 2006. Studies on nutritional and processing properties of storage roots of different yam bean (Pachyrhizus spp.) and wild mung bean (Vigna vexillata) species. Göttingen Univ., PhD Diss.

Kisambira, A., J.H. Muyonga, Y.B. Byaruhanga, P. Tukamuhabwa, S. Tumwegamire, and W. Gruenberg. 2014. Physicochemical characteristics of yam bean (Pachyrhizus erosus) seed proteins. J. Food Res. 3:168-178.

Kisambira, A., J.H. Muyonga, Y.B. Byaruhanga, P. Tukamuhabwa, S. Tumwegamire, and W.J. Grüneberg. 2015. Composition and functional properties of yam bean (Pachyrhizus spp.) seed flour. Food Nutr. Sci. 6:736-746.

Lackey, J. 1977. A revised classification of the tribe Phaseoleae (Leguminosae: Papilionoideae), and its relation to canavanine distribution. Bot. J. Linn. Soc. 74:163-178.

Lautié, E., E. Rozet, P. Hubert, N. Vandelaer, F. Billard, T. Zum Felde, W.J. Grüneberg, and J. Quetin-Leclercq. 2013. Fast method for the simultaneous quantification of toxic polyphenols applied to the selection of genotypes of yam bean (Pachyrhizus sp.) seeds. Talanta 117:94-101.

Leidi, E.O., D. Rodrìguez-Navarro, M. Fernández, R. Sarmiento, J. Semedo, N. Marques, and M. Sørensen. 2004. Factors affecting root and seed yield in ahipa (Pachyrhizus ahipa (Wedd.) Parodi), a multipurpose legume crop. Eur. J. Agron. 20:395-403.
Matos, M.C., A.A. Matos, and J.B. Vieira da Silva. 1998. Effect of manual and chemical pruning on tuber production of Pachyrhizus ahipa (Wedd.) Parodi, p. 181-189. In: M. Sørensen, J.E. Estrella, O.J. Hamann, and S.A. Ríos Ruíz (eds.). Second International Symposium on Tuberous Legumes, Celaya, Guanajuato, Mexico.

National Academy of Sciences. 2004. May 2015 $<$ https://ods.od.nih.gov/Health_Information/ Dietary_Reference_Intakes.aspx $>$.

Noman, A., M. Hoque, M. Haque, F. Pervin, and M. Karim. 2007. Nutritional and antinutritional components in Pachyrhizus erosus L. tuber. Food Chem. 102:1112-1118.

Ozaki, Y., W.F. McClure, and A. A. Christy. 2006. Near-infrared spectroscopy in food science and technology. JohnWiley \& Sons, Inc., Hoboken, NJ.

Padonou, S., A. Hounyèvou, J. Ahounou, A. Houssou, P. Fandohan, K. Aihou, A. Adjanohoun, K. Hell, P. Adégbola, G. Mensah, and D. Koudande. 2013. Yam bean (Pachyrhizus erosus) tuber processing in Benin: Production and evaluation of the quality of yam bean-gari and yam beanfortified gari. Intl. J. Biol. Chem. Sci. 7:247-259.

Park, C.J. and J.S. Han. 2015. Hypoglycemic effect of jicama (Pachyrhizus erosus) extract on streptozotocin-induced diabetic mice. Prev. Nutr. Food Sci. 20:88-93.

Payne, R.W., S.A. Harding, D.A. Murray, D.M. Soutar, D.B. Baird, and A.I. Glaser. 2011. The guide to Genstat release 14, part 2: Statistics. VSN International, Hemel Hempstead, UK.

Pfeiffer, W.H. and B. McClafferty. 2007. HarvestPlus: Breeding crops for better nutrition. Crop Sci. 47:88-105.

Ramos-de-la-Peña, A.M., C.M. Renard, L. Wicker, and J.C. Contreras-Esquivel. 2013. Advances and perspectives of Pachyrhizus spp. in food science and biotechnology. Trends Food Sci. Technol. 29:44-54.

Rizky, W.H., S. Hasani, and A. Karuniawan. 2013. Tuber yield and quality of nine genotypes yam bean (Pachyrhizus spp.) due to sink-reproductive pruning. Horticulture 62:445-448.

Rodríguez-Navarro, D.N., M. Camacho, F. Temprano, C. Santamaria, and E.O. Leidi. 2009. Assessment of nitrogen fixation potential in ahipa (Pachyrhizus ahipa) and its effect on root and seed yield. Exp. Agr. 45:177-188.

Santayana, M., G. Rossel, J. Núñez, M. Sørensen, M. Delêtre, R. Robles, V. Fernández, W.J. Grüneberg, and B. Heider. 2014. Molecular characterization of cultivated species of the genus Pachyrhizus Rich. ex DC. by AFLP markers: Calling for more data. Trop. Plant Biol. 7:121-132.

Singh, R. and B. Chaudhary. 1985. Biometrical methods in quantitative genetic analysis, p. 93101. Kalyani Publishers, New Delhi, India.

Sørensen, M. 1996. Yam bean: Pachyrhizus DC.promoting the conservation and use of underutilized and neglected crops. 2. Institute of Plant Genetics and Crop Plant Research, Gatersleben, Germany/International Plant Genetic Resources Institute, Rome, Italy.

Tumuhimbise, R., R. Melis, P. Shanahan, and R. Kawuki. 2014. Genotype $\times$ environment interaction effects on early fresh storage root yield and related traits in cassava. Crop J. 2:329-337.

Tumwegamire, S., P. Rubaihayo, D. LaBonte, F. Diaz, R. Kapinga, R. Mwanga, and W. Grüneberg. 2011. Genetic diversity in white-and orangefleshed sweetpotato farmer varieties from east Africa evaluated by simple sequence repeat markers. Crop Sci. 51:1132-1142.

Utz, H. 1997. PLABSTAT: A computer program for the computation of variances and covariances. Universität Hohenheim, Germany.

Velasco, L. and W.J. Grüneberg. 1999. Analysis of dry matter and protein contents in fresh yam bean tubers by near-infrared reflectance spectroscopy. Commun. Soil Sci. Plant Anal. 30:1797-1805.

Wilken, M.F., G.E. Erickson, J.R. Benton, C.D. Buckner, T.J. Klopfenstein, K. Karges, and M. Gibson. 2008. Evaluation of methods for dry matter determination of ethanol byproducts. Nebr. Beef Cattle Rep. 49.

Zanklan, A.S., S. Ahouangonou, H.C. Becker, E. Pawelzik, and W.J. Grüneberg. 2007. Evaluation of the storage root-forming legume yam bean (Pachyrhizus spp.) under West African conditions. Crop Sci. 47:1934-1946. 
Supplemental Table 1. Environmental characteristics of experimental locations used for field evaluations of yam bean accessions during 2012 and 2013 growing seasons.

\begin{tabular}{|c|c|c|c|c|c|c|}
\hline \multirow[b]{2}{*}{ Location } & \multirow[b]{2}{*}{ Vegetation type } & \multirow[b]{2}{*}{ Soil type } & \multirow[b]{2}{*}{ Altitude (meters above sea level) } & \multirow[b]{2}{*}{ Rain fall (mm) } & \multicolumn{2}{|c|}{ Temperature $\left({ }^{\circ} \mathrm{C}\right)$} \\
\hline & & & & & Mean & Range \\
\hline Namulonge & $\begin{array}{l}\text { Tropical rain } \\
\text { Forest }\end{array}$ & $\begin{array}{l}\text { Sandy clay } \\
(\mathrm{pH} 4.9-5.0)\end{array}$ & 1,150 & 1,320 & 22.2 & $15.5-28$ \\
\hline Serere & Tall savanna & $\begin{array}{l}\text { Sandy roam } \\
(\mathrm{pH} 5.2-6.0)\end{array}$ & 1,140 & $900-1,300$ & 26 & $23.9-30.0$ \\
\hline
\end{tabular}

Supplemental Table 2. Environmental means for yield and quality traits of yam beans accessions across four environments ( 2 locations $\times 2$ seasons).

\begin{tabular}{|c|c|c|c|c|c|c|c|c|c|c|c|c|}
\hline \multirow[b]{2}{*}{$\begin{array}{l}\text { Environment / } \\
\text { season }\end{array}$} & \multicolumn{5}{|c|}{ Yield traits } & \multicolumn{7}{|c|}{ Root quality traits } \\
\hline & $\begin{array}{c}\text { Storage } \\
\text { root fresh } \\
\text { yield } \\
\left(\mathrm{kg} \cdot \mathrm{m}^{-2}\right)\end{array}$ & $\begin{array}{c}\text { Storage } \\
\text { root dry } \\
\text { yield } \\
\left(\mathrm{kg} \cdot \mathrm{m}^{-2}\right)\end{array}$ & $\begin{array}{c}\text { Vine } \\
\text { yield } \\
\left(\mathrm{kg} \cdot \mathrm{m}^{-2}\right)\end{array}$ & $\begin{array}{c}\text { Fresh } \\
\text { biomass } \\
\text { yield } \\
\left(\mathrm{kg} \cdot \mathrm{m}^{-2}\right)\end{array}$ & $\begin{array}{c}\text { Harvest } \\
\text { index }(\%)\end{array}$ & $\begin{array}{c}\text { Root } \\
\text { dry } \\
\text { matter } \\
(\%)\end{array}$ & $\begin{array}{l}\text { Protein }{ }^{y} \\
(\%)\end{array}$ & $\begin{array}{l}\text { Starch }^{\mathrm{y}} \\
(\%)\end{array}$ & $\begin{array}{c}\operatorname{Iron}^{\mathrm{y}} \\
\left(\mathrm{mg} \cdot \mathrm{kg}^{-1}\right)\end{array}$ & $\begin{array}{c}\operatorname{Zinc}^{\mathrm{y}} \\
\left(\mathrm{mg} \cdot \mathrm{kg}^{-1}\right)\end{array}$ & $\begin{array}{c}\mathrm{K}^{\mathrm{y}} \\
(\mathrm{mg} / 100 \mathrm{~g})\end{array}$ & $\begin{array}{c}\mathrm{P}^{\mathrm{y}} \\
(\mathrm{mg} / 100 \mathrm{~g})\end{array}$ \\
\hline Namulonge 2012 & 22.1 & 2.7 & 3.9 & 26.4 & 84.6 & 13.4 & 10.0 & 51.3 & 23.3 & 13.2 & 1,138 & 235 \\
\hline Namulonge 2013 & 10.7 & 1.3 & 1.5 & 12.2 & 76.1 & 13.1 & 11.2 & 52.3 & 28.7 & 15.0 & 1,084 & 268 \\
\hline Namulonge mean & 16.4 & 2.0 & 2.7 & 19.3 & 80.4 & 13.2 & 10.6 & 51.8 & 26.0 & 14.1 & 1,111 & 251 \\
\hline Serere 2012 & 12.2 & 1.8 & 4.5 & 16.6 & 75.5 & 17.3 & 7.9 & 51.3 & 15.4 & 9.9 & 937 & 167 \\
\hline Serere 2013 & 6.2 & 0.9 & 2.8 & 9.0 & 72.4 & 17.2 & 9.4 & 50.4 & 24.0 & 11.6 & 815 & 212 \\
\hline Serere mean & 9.2 & 1.4 & 3.6 & 12.8 & 74.0 & 17.3 & 8.6 & 50.8 & 19.7 & 10.7 & 878 & 191 \\
\hline Grand mean & 12.8 & 1.7 & 3.2 & 16.1 & 77.2 & 15.3 & 9.6 & 51.3 & 22.9 & 12.4 & 993 & 221 \\
\hline $\operatorname{LSD}^{x}(0.05)$ & 5.7 & 0.7 & 1.6 & 6.5 & 10.7 & 1.2 & 0.7 & 6.5 & 1.5 & 1.3 & 101 & 23 \\
\hline
\end{tabular}

${ }^{\mathrm{z}}$ On a fresh weight basis.

${ }^{\mathrm{y}}$ On a dry weight basis.

${ }^{\mathrm{x}} \mathrm{LSD}$, least significant difference at the 0.05 level with all factors considered as fixed except replication.

Supplemental Table 3. Mean squares for yield components and nutritional quality traits from the analysis of variance.

\begin{tabular}{|c|c|c|c|c|c|c|c|c|}
\hline \multirow[b]{2}{*}{ Source of variation ${ }^{z}$} & \multirow[b]{2}{*}{ df } & \multicolumn{6}{|c|}{ Mean squares for yield components } & \multirow[b]{2}{*}{ Storage root dry matter } \\
\hline & & \multicolumn{2}{|c|}{ Storage root fresh yield } & Storage root dry yield & Vine yield & Fresh biomass yield & Harvest index & \\
\hline Season & 1 & \multicolumn{2}{|c|}{$3,979.5^{*}$} & $67.8 *$ & $210.3^{*}$ & $6,209.8 * *$ & $1,769.9$ & 2.0 \\
\hline Location & 1 & \multicolumn{2}{|c|}{$2,737.7$} & 18.1 & 44.7 & $2,222.3$ & $2,145.8$ & 850.0 \\
\hline $\mathrm{L} \times \mathrm{S}$ & 1 & \multicolumn{2}{|c|}{390.6} & 2.5 & 5.3 & 555.8 & 375.8 & 0.2 \\
\hline $\mathrm{B}(\mathrm{L} \times \mathrm{S})$ & 4 & \multicolumn{2}{|c|}{$219.5^{*}$} & $3.4 *$ & $16.3 *$ & $282.1^{*}$ & $778.6^{* *}$ & 10.4 \\
\hline Genotype & 25 & \multicolumn{2}{|c|}{$571.2 * *$} & $6.6^{*}$ & $29.9 *$ & $720.5 * *$ & $812.4 * *$ & $95.0 * *$ \\
\hline $\mathrm{G} \times \mathrm{S}$ & 25 & \multicolumn{2}{|c|}{$130.2 * *$} & $2.6^{*}$ & $11.7 * *$ & $151.3 *$ & $600.9 * *$ & $7.4^{*}$ \\
\hline $\mathrm{G} \times \mathrm{L}$ & 25 & \multicolumn{2}{|c|}{139.4} & 2.0 & 13.7 & 136.3 & $1,200.1 *$ & $17.9 * *$ \\
\hline $\mathrm{G} \times \mathrm{L} \times \mathrm{S}$ & 25 & \multicolumn{2}{|c|}{$120.1 *$} & 1.8 & $20.1 * *$ & $169.3 * *$ & $545.2 * *$ & 4.7 \\
\hline \multirow[t]{2}{*}{ Error } & & \multicolumn{2}{|c|}{64.8} & 1.3 & 5.0 & 81.3 & 219.3 & 4.4 \\
\hline & & & \multicolumn{6}{|c|}{ Mean squares for root quality traits ${ }^{y}$} \\
\hline Source of variation & & df & Protein & Starch & Iron & Zinc & Potassium & Phosphorous \\
\hline Season & & 1 & $94.0 * *$ & 0.13 & $2,518.8^{* *}$ & $150.4^{*}$ & 402,578 & $79,740^{* *}$ \\
\hline Location & & 1 & 211.6 & 46.4 & $2,076.7$ & 583.1 & 284,448 & 201,122 \\
\hline $\mathrm{S} \times \mathrm{L}$ & & 1 & 0.8 & 44.7 & $131.2 *$ & 0.2 & 60,270 & 1,898 \\
\hline $\mathrm{B}(\mathrm{L} \times \mathrm{S})$ & & 4 & 3.0 & $281.1^{*}$ & 14.8 & 12.2 & 68,930 & 3,553 \\
\hline Genotype & & 25 & 3.9 & $480.1^{*}$ & $190.9 *$ & 15.5 & 491,369 & 4,597 \\
\hline $\mathrm{G} \times \mathrm{S}$ & & 25 & $4.0 *$ & $195.4^{*}$ & 73.7 & $11.0^{* *}$ & $291,803 * *$ & $5,220 *$ \\
\hline $\mathrm{G} \times \mathrm{L}$ & & 25 & 2.7 & 127.5 & 73.6 & 8.2 & 216,025 & 5,871 \\
\hline $\mathrm{G} \times \mathrm{S} \times \mathrm{L}$ & & 25 & 2.3 & 164.4 & 90.0 & 6.1 & $252,090 * *$ & 3,231 \\
\hline Error & & & 2.4 & 111.4 & 126.2 & 5.2 & 122,158 & 2,828 \\
\hline
\end{tabular}

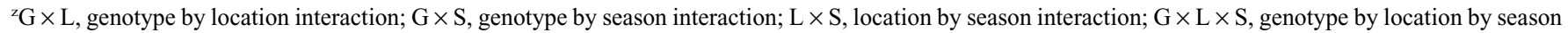
interaction.

${ }^{\mathrm{y}}$ On a dry weight basis.

*,**Significant at $P$ value 0.05 and 0.01 , respectively. 